\title{
The Synergistic Effect of Heating and Gamma-Irradiation on the DNA Damage and Death of Deinococcus radiodurans
}

\author{
Kazuki Harada, ${ }^{*}$ Aritsune Uchida, ${ }^{*}$ and Hajime Kadota* \\ (Accepted February 8, 1984)
}

\begin{abstract}
The cells of Deinococcus radiodurans were not killed when they were independently treated by gamma-irradiation at $300 \mathrm{krad}$ or heating at $55^{\circ} \mathrm{C}$ for $8 \mathrm{~min}$. However, some synergistic effects of gamma-irradiation and mild heating on the survival of the bacterium were found when the cells were treated by the combination of these different agents, and this synergistic killing effect was irrespective of the treatment procedure.

The DNA of the cells which were heated at $55^{\circ} \mathrm{C}$ for $8 \mathrm{~min}$ immediately after gamma-irradiation at $300 \mathrm{krad}$ was more disintegrated to smaller molecular weight than that of the cells which were simply heated or irradiated. The DNA breaks caused by the combined treatment of gammairradiation and mild heating were not repaired after even 480 min incubation in growing medium.

Therefore, it is thought that the repair mechanisms of radiation-induced DNA injury and mild-heating-induced DNA injury are probably common.
\end{abstract}

The combined treatment of heat and gammairradiation to biological systems has attracted attention for some practical applications such as food sterilization and therapy by hyperthermia and ionizing radiation. Since CURRAN and EVANS ${ }^{1)}$ reported in 1938 that bacterial spores of several Bacillus species exposed to certain levels of ionizing radiation became sensitive to subsequent heating, many other researchers have reported at International Atomic Energy Agency (IAEA) symposia etc. that the combined treatments of heat and gamma-irradiation have a synergistic inactivation effect on microbial cell. SOMmer and MAXIE showed the synergistic killing effect of these treatments on several fungi in fruits and vegetables.") Similarly, STEHIIK and KaINDL found the same effect on Saccharomyces cerevisiae var. ellipsoideus. ${ }^{3)}$ A similar effect on the spores of Clostridiumperfringens, type $\mathrm{A}$, has also been reported. ${ }^{4,5}$

Further, from the view point of sterilization of interplanetary spacecraft, the synergistic inactivation of bacteria was investigated in support of the National Aeronautics and Space Administration (NASA) program. REYNolds and BRANNEN decided the optimum temperature-dose rate combination required minimum energy for sterilization using the NASA standard strain i.e. B. subtilis spores. ${ }^{0)}$

The mechanisn of combined heat-irradiation effects has also been reported in relation to DNA injury and its repair, ${ }^{7,8}$ and effects of hyperthermia on repair of radiation-induced DNA strand breaks in mammalian cells has been recently investigated. ${ }^{\theta-11}$ )

The purpose of this work is to make clear whether or not the synergistic killing effects of gamma-radiation and mild heating is recognized on the cells of Deinococcus radiodurans ${ }^{12)}$ which is highly resistant to ionizing radiation, ${ }^{13,14)}$ ultraviolet radiation, ${ }^{15)}$ heating ${ }^{7,18,17)}$ and chemical agents, ${ }^{18)}$ on the basis of survival curves and the changes of the DNA sedimentation profiles. The similarity of repair mechanism of DNA injuries by mild heating and radiation in $D$. radiodurans is also discussed.

\section{Materials and Methods}

\section{Organisms}

D. radiodurans $\mathrm{R} 1$ (ATCC 13939) obtained from the American Type Culture Collection, Maryland, was used throughout this work. A Marburg strain of B. subtilis 3610 (ATCC 6051) was used as a reference.

\section{Preparation of Cells}

The non-labeled and DNA-labeled cells of $D$. radiodurans were obtained as previously described. ${ }^{10)}$ Non-labeled cells were harvested at logarithmic growth phase or stationary phase.

* Laboratory of Microbiology, Department of Fisheries, Faculty of Agriculture, Kyoto University, Kyoto 606, Japan（原田和樹・内田有恆・門田 元：京都大学掌部水産微生物学研究空). 
In order to obtain $B$. subtilis spores, after being incubated in the liquid medium for $20 \mathrm{~h}$, the cells were incubated on nutrient agar at $37^{\circ} \mathrm{C}$ for 5 days. Then, spores were harvested and purified by washing with distilled water after incubation at $37^{\circ} \mathrm{C}$ for $40 \mathrm{~min}$ with $500 \mu \mathrm{g} / \mathrm{ml}$ of lysozyme.

\section{Gamma-Irradiation}

The cells were suspended in $\mathrm{M} / 15$ phosphate buffer ( $\mathrm{pH} 7.0)$ at a cell concentration of approximately $1 \times 10^{8}$ colony forming units $/ \mathrm{ml}$. Gammairradiation was carried out in a ${ }^{80} \mathrm{Co}$ source at a dose rate of $16.5 \mathrm{krad} / \mathrm{min}$ in Osaka Laboratory for Radiation Chemistry, Japan Atomic Energy Research Institute. These cell suspensions were irradiated at room temperature.

\section{Preheating or Postheating Gamma-Irradiation}

Heat treatment of this organism was carried out as described previously. ${ }^{17)}$ The cells were treated with heating immediately after or before gammairradiation.

\section{Counting of the Survivors}

As for $D$. radiodurans, the B-broth with $1.5 \%$ agar was used for enumeration of the cells which survived after various treatments. ${ }^{20)}$

As for B. subtilis, the nutrient broth ${ }^{21}$ with $1.5 \%$ agar was used, and colonies were counted after incubation at $37^{\circ} \mathrm{C}$ for 2 days.

Preparation of Spheroplasts and Extraction of DNA

The cells were converted to spheroplasts and then DNA was extracted as described previously. ${ }^{19)}$

Sedimentation Analysis of ${ }^{3} \mathrm{H}$-Labeled DNA in Alkaline Sucrose Density Gradient

Zone sedimentation of DNA was performed as described previously. ${ }^{1 \theta)}$

Sedimentation Analysis of Purified DNA in Alkaline Sucrose Density Gradient

The DNA of $D$. radiodurans cells was extracted and purified according to the method of MARMUR. ${ }^{22)}$ The purified DNA was dissolved in SSC solution $(0.15 \mathrm{M} \mathrm{NaCl}$ and $0.015 \mathrm{M}$ sodium citrate, $\mathrm{pH} 7.0)$. The native DNA and DNA irradiated with gammarays were layered on a $4.8 \mathrm{ml}$ linear $5 \sim 20 \%$ alkaline sucrose density gradient ( $\mathrm{pH}$ 12.0) and centrifuged at $35,000 \mathrm{rpm}$ for $4 \mathrm{~h}$ at $5^{\circ} \mathrm{C}$ in a Beckman SW-50.1 rotor. The gradients were analyzed in an ISCO density gradient fractionator and

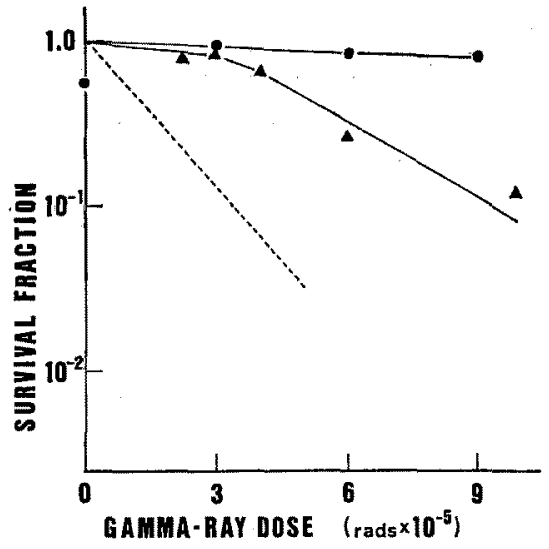

Fig. 1. Gamma irradiation survival curves of $D$. radiodurans.

-, R1 cells harvested at stationary phase; $\boldsymbol{\Lambda}$, R1 cells harvested at logarithmic growth phase; ,---- , spores of $B$. subtilis 3610 .

UV-absorbance/fluorescence monitor (Model UA5).

\section{Results}

Sensitivity of Gamma-Irradiation of D. radiodurans

The dose-response survival curves with respect to colony-forming ability of $D$. radiodurans are shown in Fig. 1. The cells of logarithmic growth phase of $D$. radiodurans $\mathrm{R} 1$ were very resistant to gamma-irradiation as compared with $B$. subtilis 3610 spores; the formers were not inactivated even by $400 \mathrm{krad}$ of gamma-irradiation. Moreover, the cells of $D$. radiodurans $\mathrm{R} 1$ at the stationary phase were more resistant than that of logarithmic growth phase, and were not inactivated even by $900 \mathrm{krad}$ of gamma-irradiation.

On the other hand we had reported that the cells were not killed by heating at $55^{\circ} \mathrm{C}$ for $8 \mathrm{~min}$ and that after $8 \mathrm{~min}$ they were killed exponentially. This organism was more resistant to heat than the vegetative cells of $B$. subtilis 168 (thy ${ }^{-}, \operatorname{trp}^{-}$) strain. $^{10,17)}$

\footnotetext{
Injury of DNA Molecules Induced by GammaIrradiation and Its Repair in D. radiodurans

Cells irradiated with 300 krad gamma-rays and non-irradiated cells were subjected to sedimentation analysis by use of alkaline sucrose density gradients. As shown in Fig. 2, the sedimentation rate of the main component of labeled DNA was decreased by $300 \mathrm{krad}$ irradiation. The results shown in Figs. 1 and 2 indicate that in spite of
} 


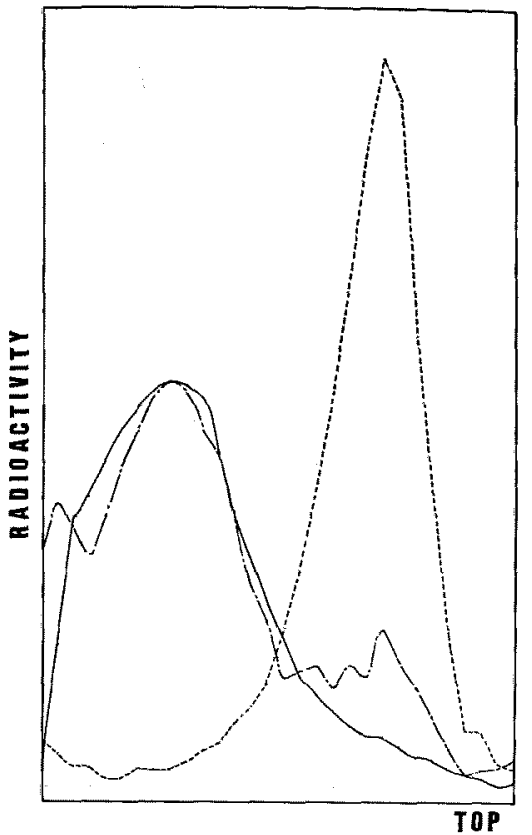

Fig. 2. Rejoining of DNA strand breaks by gammairradiation in $D$. radiodurans $\mathrm{R} 1$ cells during postirradiation incubation in B-broth at $30^{\circ} \mathrm{C}$ for 180 min.

The cells were grown in B-broth with Imethyl$\left.{ }^{5} \mathrm{H}\right]$ thymidine added. After being cultivated to the logarithmic growth phase, the cells were irradiated or incubated after irradiation, and $\left[{ }^{3} \mathrm{H}\right]$ DNA was immediately extracted by the method as described by WerBulL. DNA was layered on a linear $5 \sim 20 \%$ alkaline sucrose density gradient (pH 12.0) and centrifuged at $38,000 \mathrm{rpm}$ for $120 \mathrm{~min}$ at $20^{\circ} \mathrm{C}$ in a Beckman SW-50.1 rotor. The direction of sedimentation is from right to left. __ , unirradiated control; -...-., irradiated with $300 \mathrm{krad}$ of gamma-rays; -..-.-, incubated at $30^{\circ} \mathrm{C}$ for $180 \mathrm{~min}$ in $\mathrm{B}$-broth after irradiation.

partial degradation of DNA molecules in the cells of $D$. radiodurans the cells were not killed by irradiation with $300 \mathrm{krad}$ gamma-rays and that the DNA injury was restored during post-irradiation incubation.

In the next step, rejoining process of the gammairradiation-induced DNA breaks in the cells during post-irradiation incubation was examined. The sedimentation rate of the main component of DNA in the irradiated cells was increased with the lapse of time of post-irradiation incubation in the growing medium (B-broth). After $3 \mathrm{~h}$ incubation in B-broth, the DNA breaks were completely restored (Fig. 2).

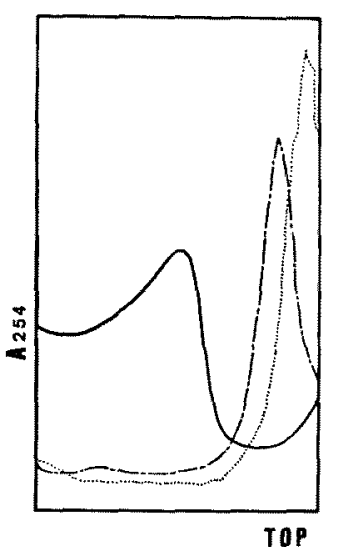

Fig. 3. Alkaline sucrose density gradient profiles of purified DNA from $D$. radiodurans irradiated with gamma-rays.

The cells were grown in B-broth to the logarithmic growth phase, and the DNA was extracted and purified according to the method of MARMUR. The native DNA and DNA irradiated with gamma-rays were layered on a $4.8 \mathrm{~m} /$ linear $5 \sim$ $20 \%$ alkaline sucrose density gradient $(\mathrm{pH} 12.0)$ and centrifuged at $35,000 \mathrm{rpm}$ for $4 \mathrm{~h}$ at $5^{\circ} \mathrm{C}$ in a Beckman SW-50.1 rotor. The direction of sedimentation is from right to left. - unirradiated control; -.-.--, irradiated with $22 \mathrm{krad}$ of gamma-rays; -....-, irradiated with $100 \mathrm{krad}$ of gamma-rays.

As described previously $D$. radiodurans cells are not killed at $55^{\circ} \mathrm{C}$ for $8 \mathrm{~min}$ and the DNA breaks are completely restored during $5.5 \mathrm{~h}$ post-heating incubation in B-broth, in spite of the partial heatinduced breaks of DNA molecules in the cells by this treatment. ${ }^{17)}$

\section{Injury of Purified DNA Molecules of D. radiodurans} Induced by Gamma-Irradiation

In order to investigate whether or not DNA constitution and base composition of this organism contribute to high resistance against gammairradiation, effect of gamma-irradiation on purified DNA was investigated. As shown in Fig. 3, according to the sedimentation analysis of DNA in alkaline sucrose density gradient, the sedimentation rate of the main component of purified DNA was decreased by only $22 \mathrm{krad}$ irradiation. With $100 \mathrm{krad}$ the DNA was completely degraded.

Effect of the Combined Treatment on Survival Curves of D. radiodurans

Gamma irradiation dose-survival curves of $D$. radiodurans being postheated or preheated at $55^{\circ} \mathrm{C}$ 


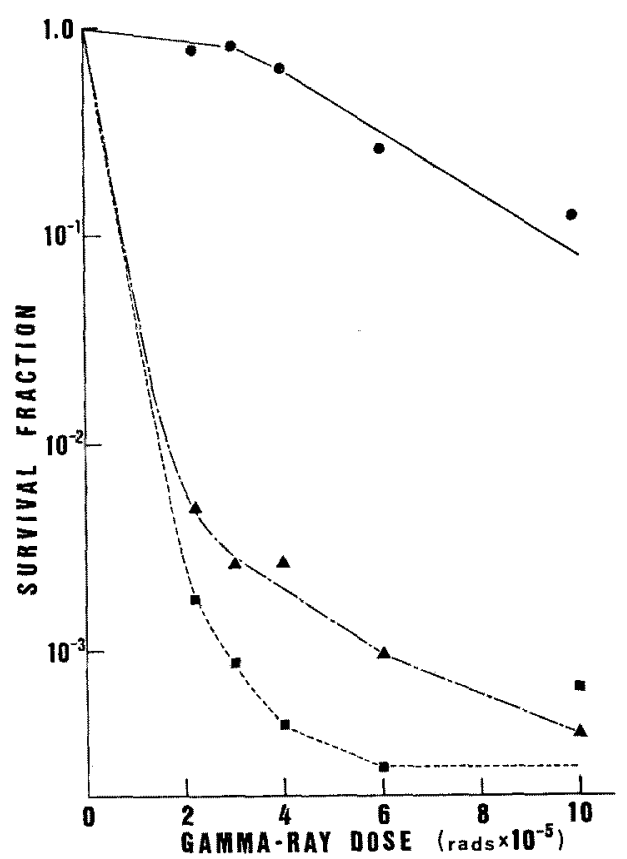

Fig. 4. Gamma irradiation survival curves of $D$. radiodurans being preheated or postheated.

The cells at logarithmic growth phase were used. control; $\Lambda$, heated at $55^{\circ} \mathrm{C}$ for $8 \mathrm{~min}$ before irradiation; $\mathrm{n}$, heated at $55^{\circ} \mathrm{C}$ for $8 \mathrm{~min}$ after irradiation.

for $8 \mathrm{~min}$ are shown in Fig. 4. The survival curves plotted against gamma-irradiation dose and heating time of $D$. radiodurans $\mathrm{R} 1$ are distinguished by large shoulders ${ }^{17}$ ) (Figs. 1 and 4). The cells were not killed when they were independently irradiated at $300 \mathrm{krad}$ or heated at $55^{\circ} \mathrm{C}$ for $8 \mathrm{~min}$. However, the combined irradiation-heat treatment resulted in enhanced synergistic killing effect. Postirradiation heating or preirradiation heating decreased the survival fraction to $0.1 \%$; the shoulders of the survival curves disappeared by these treatments. Also, heat survival curves of this organism being postirradiated or preirradiated showed the similar synergistic effect (data not shown).

Sedimentation Analysis of DNA in D. radiodurans Cells Treated by the Combination of GammaIrradiation and Heating

The sedimentation profiles of DNA of $D$. radiodurans cells which were treated with gammairradiation and/or heating are shown in Fig. 5. Single-strand DNA breaks of the cells irradiated

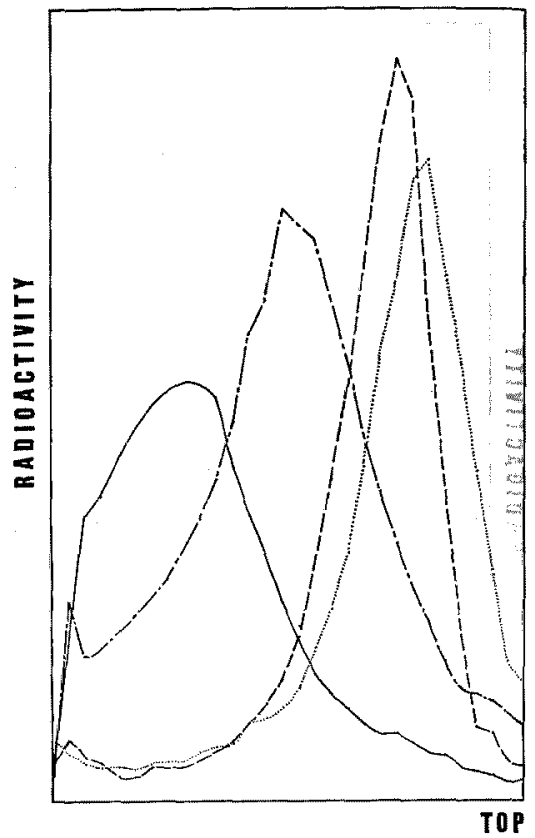

Fig. 5. Sedimentation patterns in alkaline sucrose density gradients of DNA of $D$. radiodurans cells.

Details of the method of cultivation and sedimentation analysis were described in legend of Fig. 2. - control; -..-., heated at $55^{\circ} \mathrm{C}$ for 8 min; --.- , irradiated with $300 \mathrm{krad}$ of gammarays; $\cdots \cdots$, irradiated with $300 \mathrm{krad}$ of gammarays and then immediately heated at $55^{\circ} \mathrm{C}$ for 8 min.

at $300 \mathrm{krad}$ occurred to some extent as well as those of the cells heated at $55^{\circ} \mathrm{C}$ for $8 \mathrm{~min}$, and restoration of the molecular weight of DNA took place during post-irradiation incubation or postheating incubation in B-broth ${ }^{17)}$ (Fig. 2). DNA of the cells which were heated at $55^{\circ} \mathrm{C}$ for $8 \mathrm{~min}$ immediately after irradiation at $300 \mathrm{krad}$ was found at a position of smaller molecular weight than that of the cells which were simply heated or irradiated. The DNA breaks caused by the combined treatment of gamma-irradiation and mild heating were not repaired after even $480 \mathrm{~min}$ incubation in B-broth (Fig. 6). Also when the cells were treated with the contrary procedure i.e. irradiated at $300 \mathrm{krad}$ immediately after heating at $55^{\circ} \mathrm{C}$ for $8 \mathrm{~min}$, the DNA breaks caused by the combined treatment further proceeded after 480 min incubation in B-broth (Fig. 7).

\section{Discussion}

GOMEZ and his coworkers ${ }^{4)}$ reported that in 


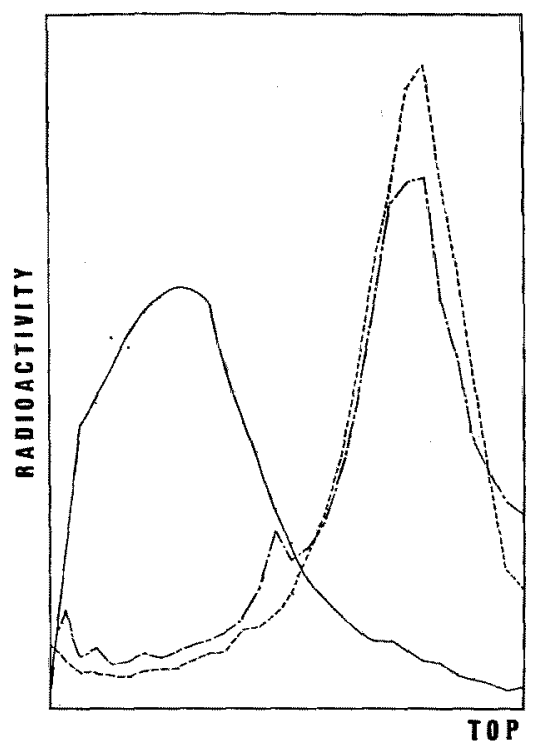

Fig. 6. Sedimentation patterns in alkaline sucrose density gradients of DNA of $D$. radiodurans cells. Details of the method of cultivation and sedimentation analysis were described in legend of Fig. 2. - control; --_-, irradiated with 300 krad of gamma-rays and then immediately heated at $55^{\circ} \mathrm{C}$ for $8 \mathrm{~min} ;-. .--$, irradiated with 300 krad of gamma-rays, immediately heated at $55^{\circ} \mathrm{C}$ for $8 \mathrm{~min}$ and incubated at $30^{\circ} \mathrm{C}$ for $480 \mathrm{~min}$ in $\mathrm{B}$ broth.

spores of $C$. perfringens, type $\mathrm{A}$, prior heating that was sufficient to inactive 40 to $99 \%$ of the viable spores had no effect on the subsequent gamma-radiation inactivation rate, and that prior irradiation had a sensitizing effect on subsequently in heated spores. And they inferred that the induction of heat sensitivity in spores by gammairradiation is related to the loss of osmoregulatory or dehydrating mechanisms in irradiated spores. ${ }^{5}$ On the contrary, SoMmer and MAXIE observed the synergism on some fungi when heating preceded gamma-irradiation. ${ }^{2)}$

Furthermore, it was reported that some species of microorganisms were more sensitized to radiation by simultaneous heating than irradiation before or after heating. ${ }^{2, B, 8)}$

Concerning the DNA damage by synergism, ORAZAWA and MATSUYAMA ${ }^{8)}$ reported that in the sedimentation analysis of DNA of Escherichia coli cells the process of the synergistic interaction might involve the inhibition of the recovery from the injury caused by heating and of the repair of DNA damaged by gamma-irradiation and that the syner-

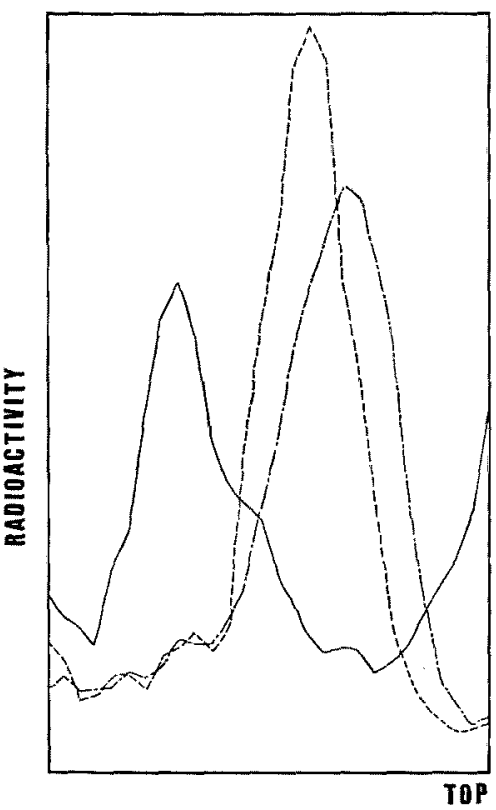

Fig. 7. Sedimentation patterns in alkaline sucrose density gradients of DNA of $D$. radiodurans cells.

Details of the method of cultivation and sedimentation analysis were described in legend of Fig. 2. - - , control; ----, heated at $55^{\circ} \mathrm{C}$ for $8 \mathrm{~min}$ and then immediately irradiated with 300 krad of gamma-rays; -...-., heated at $55^{\circ} \mathrm{C}$ for $8 \mathrm{~min}$, immediately irradiated with $300 \mathrm{krad}$ of gamma-rays and incubated at $30^{\circ} \mathrm{C}$ for $480 \mathrm{~min}$ in B-broth.

gism mechanism might not involve an increase in the number of DNA strand breaks. On the contrary, as for the cells of $D$. radiodurans, KITAYAMA and his coworkers reported ${ }^{23,24)}$ that the synergistic killing effect occurred by the combined gamma-irradiation and non-permissive growth temperature of $42^{\circ} \mathrm{C}$, but the single-strand DNA breaks caused by gamma-irradiation were completely repaired during heating at $42^{\circ} \mathrm{C}$ after gammairradiation.

We showed in this work that a combined gamma-irradiation-heat treatment had synergistic killing effect on $D$. radiodurans, and that this treatment resulted in the effect irrespective of the treatment procedure. The data reported here showed that although $D$. radiodurans have the strong DNA repair ability, DNA of the cells of this organism treated with combined heat-irradiation was found at a position of smaller molecular weight than the DNA of the cells which were simply heated or irradiated unlethally, and that the DNA breaks were 
not repaired by the incubation after the combined treatment.

The resemble results were obtained in the hyperthermia of Chinese hamster ovary $(\mathrm{CHO})$ cells (X-rays and heating at $45.5^{\circ} \mathrm{C}$ ). ${ }^{\theta-11)}$

If the repair mechanisms of irradiation-induced DNA injury and mild-heat-induced DNA injury are different, it is possible that the synergistically damaged DNA is partly repaired, because it is thought that repair enzymes for heat-damaged DNA such as APendonucleases are not disintegrated by gamma-irradiation. However, as described above the DNA breaks were not repaired at all by the long time incubation.

Therefore, it is supposed that the repair mechanisms are probably common.

\section{Acknowledgements}

The authors wish to thank Mr. T. ITOH for his technical assistance. This work was supported in part by a Grant-in-Aid for Scientific Research from the Ministry of Education, Science and Culture of Japan (Project No. 56480052).

\section{References}

1) H. R. CurRAN and F. R. Evans: J. Bacteriol, 36, 455-465 (1938).

2) N. F. SOMmer and E. C. MAXIE: in "Food Irradiation", International Atomic Energy Agency, Vienna, 1966, pp. 571-587.

3) G. Stehlik and $K$. KaIndL: in "Food Irradiation", International Atomic Energy Agency, Vienna, 1966, pp. 299-305.

4) D. E. Gombas and R. F. Gomez: Appl. Environ. Microbiol., 36, 403-407 (1978).

5) R. F. GomeZ, D. E. Gombas, and A. Herrero: Appl. Environ. Microbiol., 39, 525-529 (1980).

6) M. C. ReYnolds and J. P. Brannen: in "Radi- ation Preservation of Food", International Atomic Energy Agency, Vienna, 1972, pp. 165-176.

7) B. A. BRmges, M. J. Ashwood-SMTtr, and R. J. Munson: J. Gen. Microbiol., 58, 115-124 (1969).

8) Y. Okazawa and A. Matsuyama: in "Food Preservation", International Atomic Energy Agency, Vienna, 1978, pp. 251-262.

9) E.P. CLARK, W.C. DEWEY, and J.T. LeTT: Radiat. Res., 85, 302-313 (1881).

10) G. T. BowDEN and M. D. Kasunic: Radiat. Res., 87, 109-120 (1981).

11) M.D. MrLls and R. E. MEYN: Radiat. Res., 87, 314-328 (1981).

12) B. E. B. Moseley: in "Photochemical and Photobiological Reviews", Vol. 7, Plenum Press, 1983, pp. 223-274.

13) A. W. Anderson, H. C. Nordan, R. F. Cain, G. Parrish, and D. Duggan: Food Technol, 10, 575-578 (1956).

14) Y. Orazawa and A. Matsuyama; Agric. Biol. Chem., 31, 1505-1508 (1967).

15) B. E. B. MOSELEY and H. LASER: Nature, 206, 373-375 (1965).

16) A. UChidA, Y. SAKo, and H. Kadota: Bull. Japan. Soc. Sci. Fish., 43, 779 (1979).

17) A. UChIDA, K. HARAda, and H. Kadota: Bull. Japan. Soc. Sci. Fish., 45, 995-999 (1979).

18) D. M. SweEt and B. E. B. Moseley: Mutation Res., 34, 175-186 (1976).

19) K. Harada, A. UChida, and H. Kadota: Agric. Biol. Chem., 48, 59-65 (1984).

20) K. Harada, A. Uchma, and H. Kadota: Bull. Japan. Soc. Sci. Fish., 48, 415-419 (1982).

21) A. Uchida, I. Watanabe, K. Harada, Y. Sako, and H. Kadota: Bull. Japan. Soc. Sci. Fish., 43, 1009-1013 (1977).

22) J. MARMUR: J. Mol. Biol., 3, 208-218 (1961).

23) H. O. Cho, S. Kitayama, and A. Matsuyama: Radiat. Res., 60, 333-341 (1974).

24) S. Kitayama and A. Matsuyama: in "Microbial Ecology 8" (compiled by Japanese Society of Microbial Ecology), Japan Scientific Societies Press, Tokyo, 1980, pp. 65-85. 